\title{
Product life cycle assessment (LCA) in the environmental engineering and management aspects
}

\begin{abstract}
Environmental pollution is an ever found crux with the industrialized world although able to prevent or minimize the environmental pollution through some proper environmental management system. Product life cycle assessment (LCA) is a method of environmental assessment especially for the future plans, products and projects although it is able to assess only the environmental impacts through the product life cycle assessment (LCA). According to the methodology of the implementation of the product life cycle assessment (LCA), it is possible to continue at different stages of the relevant activities as necessary. The implementation of the assessment is done based on four key steps namely as goal and scope definition, inventory analysis, impact assessment and the interpretation. Under this assessment, basically it is expected to prevent the environmental impacts, mitigate the environmental impacts or find a solution for a future problem that relevant with the activity this is proposed.
\end{abstract}

Volume 4 Issue 6 - 2019

\author{
Jagath Kulathilaka,' Suresh Aluvihara ${ }^{2}$ \\ 'Department of Management Sciences, Uva Wellassa University, \\ Badulla, Sri Lanka \\ ${ }^{2}$ Department of Chemical and Process Engineering, University of \\ Peradeniya, Peradeniya, Sri Lanka
}

\begin{abstract}
Correspondence: Suresh Aluvihara, Department of Chemical and Process Engineering, University of Peradeniya, Peradeniya, Sri Lanka, Email sureshalvihare@gmail.com
\end{abstract}

Received: November 02, 2019 | Published: November 21, 2019

Keywords: life cycle assessment, environmental impact, inventory analysis, impact assessment, environmental pollution control

\section{Introduction}

Regarding the most of industrial and manufacturing processes it is commonly found some problems that need to be solved in various ways. In fact that the Environmental Pollution is some sort of risky aspect that related with the industrial processes even though it is able to minimize through a proper Environmental Management system. ${ }^{1-3}$ The major Environmental Impacts found with respect to some specific industrial processes as given in the Table 1 .

Table I Pollutants and their environmental impacts

\begin{tabular}{|c|c|c|}
\hline Pollutants & Environmental impacts & Relevant activities \\
\hline $\mathrm{CO}_{2}$ & $\begin{array}{l}\text { Global warming (Green } \\
\text { house gas) and Acid rain }\end{array}$ & Fossil fuel burning \\
\hline $\mathrm{NO}_{X(X=1 / 2,1,2,3)}$ & $\begin{array}{l}\text { Global warming (Green } \\
\text { house gas) and acid rain }\end{array}$ & Vehicle emissions \\
\hline $\mathrm{CO}$ & Diseases for human beings & Semi combustions \\
\hline $\mathrm{SO}_{X(X=2,3)}$ & Acid rain & Coal burning \\
\hline $\mathrm{CH}_{4}$ & $\begin{array}{l}\text { Global warming (Green } \\
\text { house gas) }\end{array}$ & Dumping sites \\
\hline Waste water & $\begin{array}{l}\text { Contamination of water } \\
\text { bodies and sources }\end{array}$ & $\begin{array}{l}\text { Industrial activities } \\
\text { and wastes }\end{array}$ \\
\hline
\end{tabular}

Therefore, the environmental management system plays a significant role in the protection of the environment. Product life cycle assessment (LCA) is a method that it is able to identify some specific impact before the happening. The preliminaries, methodology and applications of product life cycle assessment (LCA) have been discussed in the following sections. ${ }^{1-5}$

\section{Life cycle assessment (LCA)}

Basically through the Life Cycle Assessment (LCA), the solutions are found for the Environmental Impacts and the Health Impacts especially in following stages with respect to some specific product. a. Raw material exploration and extraction stage

b. Stage of preprocessing, collection and transportation of raw materials

c. Production and manufacturing stage

d. Distribution stage

e. Uses of the product stage

f. Disposal, recovery, reuse or recycle stage

The relevant procedure of the implementation of the Life Cycle Analysis (LCA) has been described with the appropriate example as given in the below. ${ }^{1-6}$

A, B, C and D are four same products for the similar requirements and same function although which are producing under four different processes in different factories. Therefore, those productions may have different properties. For the production of $1 \mathrm{~kg}$ of each of following products the relevant data have been assumed as given in following Tables $2-5$.

The above data were used in the following steps of the product life cycle analysis (LCA) accordingly as the purposes.

\section{Goal and scope definition}

This is the initial step of the product life cycles assessment (LCA) and in this stage mainly it is considered about the relevant product, activity, project or plan by defining the relevant purposes of existing study and defining some appropriate system boundaries for such

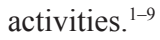

Product A Product B Product C Product D

Goal: Determination of the overall environmental impact from some specific amounts of product $\mathrm{A}$, product $\mathrm{B}$, product $\mathrm{C}$ and product D. 
Table $2 \mathrm{NO}_{x}$ emissions for $\mathrm{l} \mathrm{kg}$ of each production

\begin{tabular}{lllll}
\hline Product & $\begin{array}{l}\text { Raw material } \\
\text { extraction } \\
\text { phase } \mathbf{( g / k g )}\end{array}$ & $\begin{array}{l}\text { Transportation phase } \\
\mathbf{( g / k g )}\end{array}$ & $\begin{array}{l}\text { Production phase } \\
\mathbf{( g / \mathbf { k g } )}\end{array}$ & $\begin{array}{l}\text { Recycle phase } \\
\mathbf{( g / k g )}\end{array}$ \\
\hline Product A & 2 & 30 & 20 & 1 \\
Product B & 1 & 25 & 35 & 2 \\
Product C & 3 & 50 & 15 & 10 \\
Product D & 8 & 40 & 45 & 3 \\
\hline
\end{tabular}

Table $3 \mathrm{SO}_{2}$ emissions for $\mathrm{lkg}$ of each production

\begin{tabular}{lllll}
\hline Product & $\begin{array}{l}\text { Raw material } \\
\text { extraction } \\
\text { phase }(\mathbf{g} / \mathbf{k g})\end{array}$ & Transportation phase & Production phase & Recycle phase \\
\hline (g/kg) & $\mathbf{( g / k g )}$ & $\mathbf{( g / k g )}$ \\
\hline Product A & 5 & 4 & 7 & 12 \\
Product B & 2 & 6 & 8 & 15 \\
Product D & 6 & 9 & 14 & 7 \\
\hline
\end{tabular}

Table 4 Water consumptions for $\mathrm{lkg}$ of each production

\begin{tabular}{lllll}
\hline Product & $\begin{array}{l}\text { Raw material } \\
\text { extraction } \\
\text { phase (1/kg) }\end{array}$ & $\begin{array}{l}\text { Transportation phase } \\
\text { (I/kg) }\end{array}$ & $\begin{array}{l}\text { Production phase } \\
\text { (1/kg) }\end{array}$ & $\begin{array}{l}\text { Recycle phase } \\
\text { (1/kg) }\end{array}$ \\
\hline Product A & 2 & - & 4 & 7 \\
Product B & 1 & - & 6 & 10 \\
Product C & 4 & - & 5 & 3 \\
Product D & 5 & - & 3 & 4 \\
\hline
\end{tabular}

Table 5 Solid waste generations for $\mathrm{lkg}$ of each production

\begin{tabular}{lllll}
\hline Product & $\begin{array}{l}\text { Raw material } \\
\text { extraction phase } \\
(\mathbf{g} / \mathbf{k g})\end{array}$ & $\begin{array}{l}\text { Transportation phase } \\
\mathbf{( g / \mathbf { k g } )}\end{array}$ & $\begin{array}{l}\text { Production phase } \\
(\mathbf{g} / \mathbf{k g})\end{array}$ & $\begin{array}{l}\text { Recycle phase } \\
\mathbf{( g / k g )}\end{array}$ \\
\hline Product A & 6 & 4 & 3 & 9 \\
Product B & 23 & 5 & 2 & 7 \\
Product C & 15 & 6 & 9 & 12 \\
Product D & 10 & 8 & 12 & 18 \\
\hline
\end{tabular}

Defining of a functional unit: The functional unit should be descriptively common for each type of product to be compared with the other product. In addition this is called as the basis for the product life cycle assessment (LCA).

According to the above example the basis was assumed as the production of $100 \mathrm{~kg}$ of each production. Therefore, in the following steps there were expected to determine the amounts of emissions, water consumptions and solid waste generations with respect to $100 \mathrm{~kg}$ of each product.

Defining of system boundaries: The common process flow diagram
(PFD) for each product has been given in the Figure 1.

According to the process flow diagram (PFD) the environmental impacts of different phases of each product were determined and finally the total environmental impact with respect to each product was determined.

\section{Inventory analysis}

This is the second major step of product life cycle assessment (LCA). At this stage basically it was identified some relevant inputs and outputs of the each stages of the each product. 


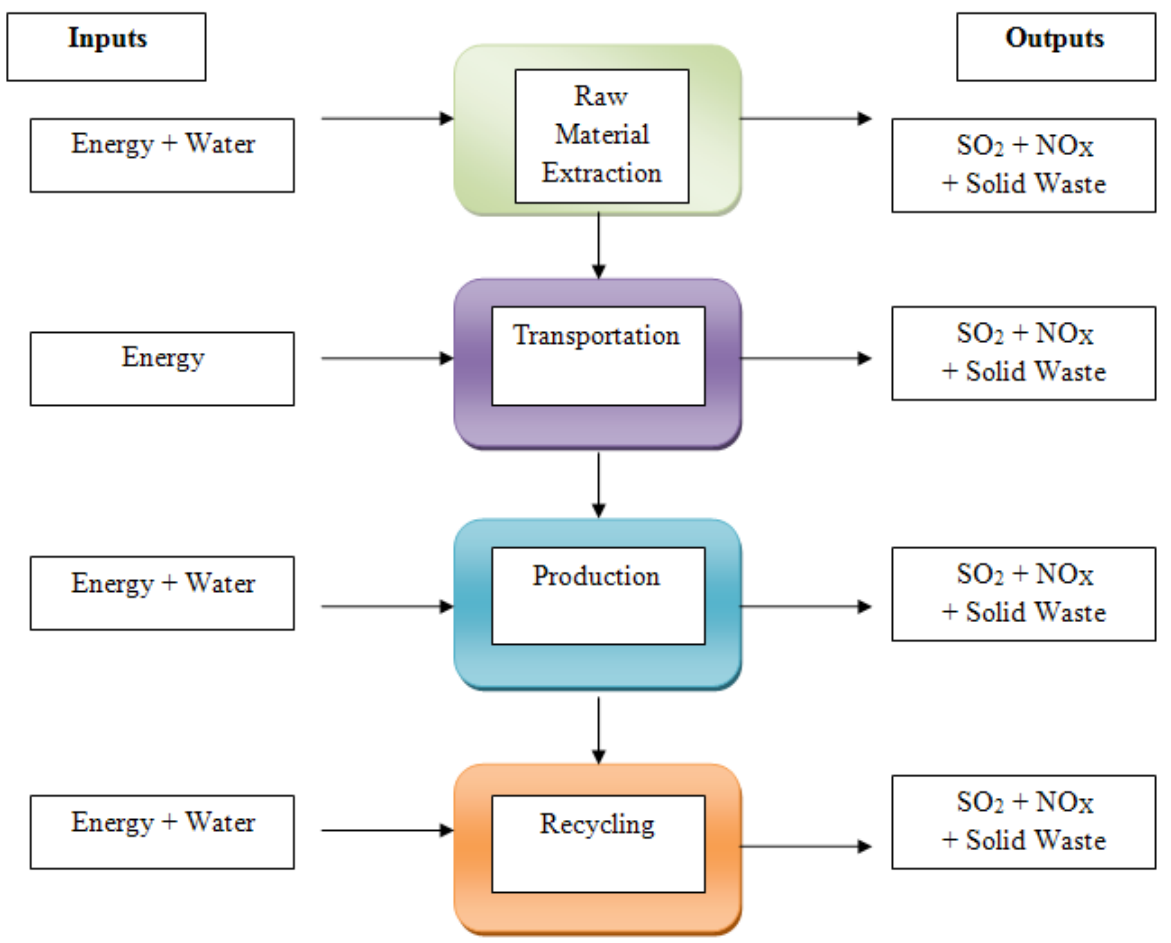

Figure I The process flow diagram (PFD).

The total emissions of $\mathrm{NO}_{\mathrm{x}}$ throughout the manufacturing of $100 \mathrm{~kg}$ of each production have been determined in the Table 6 .

The total emissions of $\mathrm{SO}_{2}$ throughout the manufacturing of $100 \mathrm{~kg}$ of each production have been determined in the Table 7 .
The total water consumptions throughout the manufacturing of $100 \mathrm{~kg}$ of each production have been determined in the Table 8 .

The total solid waste generations throughout the manufacturing of $100 \mathrm{~kg}$ of each production have been determined in the Table 9 .

Table 6 Total emissions of $\mathrm{NO}_{x}$ of $100 \mathrm{~kg}$ of each production

\begin{tabular}{|c|c|c|c|c|c|}
\hline Product & $\begin{array}{l}\text { Raw material } \\
\text { extraction phase (g) }\end{array}$ & $\begin{array}{l}\text { Transportation } \\
\text { Phase } \\
\text { (g) }\end{array}$ & $\begin{array}{l}\text { Production } \\
\text { Phase } \\
\text { (g) }\end{array}$ & $\begin{array}{l}\text { Recycle Phase } \\
\text { (g) }\end{array}$ & Total (g) \\
\hline Product $\mathrm{A}$ & 200 & 3000 & 2000 & 100 & 5300 \\
\hline Product B & 100 & 2500 & 3500 & 200 & 6300 \\
\hline Product C & 300 & 5000 & 1500 & 1000 & 7800 \\
\hline Product D & 800 & 4000 & 4500 & 300 & 9600 \\
\hline
\end{tabular}

Table 7 Total emissions of $\mathrm{SO}_{2}$ of $100 \mathrm{~kg}$ of each production

\begin{tabular}{llllll}
\hline Product & $\begin{array}{l}\text { Raw material } \\
\text { extraction phase }\end{array}$ & $\begin{array}{l}\text { Transportation } \\
\text { phase } \mathbf{( g )}\end{array}$ & $\begin{array}{l}\text { Production phase } \\
\text { (g) }\end{array}$ & $\begin{array}{l}\text { Recycle phase } \\
\text { (g) }\end{array}$ & $\begin{array}{c}\text { Total } \\
(\mathbf{g})\end{array}$ \\
\hline Product A & 500 & 400 & 700 & 1200 & 2800 \\
Product B & 200 & 600 & 800 & 1500 & 3100 \\
Product C & 900 & 900 & 1400 & 700 & 3900 \\
Product D & 600 & 500 & 600 & 2000 & 3700 \\
\hline
\end{tabular}


Table 8 Total water consumptions of $100 \mathrm{~kg}$ of each production

\begin{tabular}{|c|c|c|c|c|c|}
\hline Product & $\begin{array}{l}\text { Raw material } \\
\text { extraction } \\
\text { phase (I) }\end{array}$ & $\begin{array}{l}\text { Transportation } \\
\text { phase } \\
\text { (I) }\end{array}$ & $\begin{array}{l}\text { Production phase } \\
\text { (I) }\end{array}$ & $\begin{array}{l}\text { Recycle phase } \\
\text { (I) }\end{array}$ & $\begin{array}{l}\text { Total } \\
\text { (I) }\end{array}$ \\
\hline Product A & 200 & - & 400 & 700 & 1300 \\
\hline Product B & 100 & - & 600 & 1000 & 1700 \\
\hline Product C & 400 & - & 500 & 300 & 1200 \\
\hline Product D & 500 & - & 300 & 400 & 1200 \\
\hline
\end{tabular}

Table 9 Total solid waste generations of $100 \mathrm{~kg}$ of each production

\begin{tabular}{|c|c|c|c|c|c|}
\hline Product & $\begin{array}{l}\text { Raw material } \\
\text { extraction phase } \\
\text { (g) }\end{array}$ & $\begin{array}{l}\text { Transportation } \\
\text { phase } \\
\text { (g) }\end{array}$ & $\begin{array}{l}\text { Production phase } \\
\text { (g) }\end{array}$ & $\begin{array}{l}\text { Recycle phase } \\
\text { (g) }\end{array}$ & $\begin{array}{l}\text { Total } \\
\text { (g) }\end{array}$ \\
\hline Product A & 600 & 400 & 300 & 900 & 2200 \\
\hline Product B & 2300 & 500 & 200 & 700 & 3700 \\
\hline Product C & 1500 & 600 & 900 & 1200 & 4200 \\
\hline Product D & 1000 & 800 & 1200 & 1800 & 4800 \\
\hline
\end{tabular}

\section{Impact assessment}

In this stage mainly it was considered the estimation and determination of the environmental impacts from the identified pollutants such as the emissions and wastes. In this stage the basically analyzed the potential impact of such pollutant and the significance relevant with that. The factor may have much validity in the determination of the magnitude of such impacts. The values for the factors might be varied according to different standards and scales. There were assumed some numerical values for such factors as examples for the existing analysis and these are not standard values. The factor may have different units purposely such as the eco-points. ${ }^{1-5}$

The impacts from $\mathrm{NO}_{\mathrm{x}}$ of such products have been given in the Table 10.

The impacts from $\mathrm{SO}_{2}$ of such products have been given in the Table 11.

The impacts of water consumptions of such produc ts have been given in the Table 12.

The impacts from solid waste generation of such products have been given in the Table 13 .

\section{Interpretation}

At this stage especially it is expected to interpret the results or outcomes of above analysis. The total impacts of each product throughout the entire manufacturing process have been determined in the Table 14.

According to the overall impact analysis results that it is possible to emphasize the least environmental impact from product $\mathrm{A}$ and the highest environmental impact from product $\mathrm{D}$ throughout the manufacturing of such products. Therefore these results are important in the making of some decision to choose the most eco-friendly product among a list of product. Due to such analysis and decision there were expected to minimize or preventions of the environmental impact of some pollutants as given in the below.

i. Reduction of $\mathrm{NO}_{\mathrm{x}}$ emission-Mitigation of acid rains

ii. Reduction of $\mathrm{SO}_{2}$ emission-Prevention of smog and acid rain

iii. Reduction of water consumption-Mitigation of waste water generations and fresh water pollution

iv. Reduction of solid waste generation-Mitigation of water pollution and air pollution

In addition to the overall environmental impact analysis of each product, it is possible to analyze the impact of some specifically identified pollutant at some necessary phase of some selected production and the results should be important in the selection of mitigation options against such environmental impact. The obtained results should be compared with some reference values, norms or standard limits and it should be identified whether the specific activity is an environmental impact or not.

\section{Applications in the life cycle assessment}

a. Selection of some eco-friendly product or project among a list of such items.

b. Make some appropriate mitigation options in risky phases in the product life cycle.

c. Identification of pollutants and relevant activities.

d. Improve the quality of the product, process or project. 
Table 10 Impacts from $\mathrm{NO}_{x}$ of such products

\begin{tabular}{llll}
\hline Product & Amount /quantity (g) & Factor (units/g) & Impact (units) \\
\hline Product A & 5300 & 1.5 & 7950 \\
Product B & 6300 & 1.5 & 9450 \\
Product C & 7800 & 1.5 & 11700 \\
Product D & 9600 & 1.5 & 14400 \\
\hline
\end{tabular}

Table I I Impacts from $\mathrm{SO}_{2}$ of such products

\begin{tabular}{llll}
\hline Product & Amount /quantity (g) & Factor (units/g) & Impact (units) \\
\hline Product A & 2800 & I & 2800 \\
Product B & 3100 & I & 3100 \\
Product C & 3900 & I & 3900 \\
Product D & 3700 & I & 3700 \\
\hline
\end{tabular}

Table 12 Impacts from water consumption of such products

\begin{tabular}{llll}
\hline Product & Amount /quantity (I) & Factor (units/g) & Impact (units) \\
\hline Product A & 1300 & 0.5 & 650 \\
Product B & 1700 & 0.5 & 850 \\
Product C & 1200 & 0.5 & 600 \\
Product D & 1200 & 0.5 & 600 \\
\hline
\end{tabular}

Table 13 Impacts from solid waste generation of such products

\begin{tabular}{llll}
\hline Product & Amount /Quantity (g) & Factor (units/g) & Impact (units) \\
\hline Product A & 2200 & 0.25 & 550 \\
Product B & 3700 & 0.25 & 925 \\
Product C & 4200 & 0.25 & 1050 \\
Product D & 4800 & 0.25 & 1200
\end{tabular}

Table I 4 Total impacts of each production

\begin{tabular}{llllll}
\hline Product & $\begin{array}{l}\text { Impact of } \mathbf{N O}_{\mathbf{x}} \\
\text { (units) }\end{array}$ & $\begin{array}{l}\text { Impact of } \mathbf{S O}_{2} \\
\text { (units) }\end{array}$ & $\begin{array}{l}\text { Impact of water } \\
\text { consumption (units) }\end{array}$ & $\begin{array}{l}\text { Impact of solid waste } \\
\text { generation (units) }\end{array}$ & $\begin{array}{l}\text { Total impact } \\
\text { (units) }\end{array}$ \\
\hline Product A & 7950 & 2800 & 650 & 550 & 11950 \\
Product B & 9450 & 3100 & 850 & 925 & 1050 \\
Product C & 11700 & 3900 & 600 & 17250 \\
Product D & 14400 & 3700 & 600 & 1200 & 19900 \\
\hline
\end{tabular}




\section{Merits of life cycle assessment for the environmental management}

i. Identification or eliminate the impact of the pollution.

ii. Identification and confirmation of renewable and non- renewable resources.

iii. Improve and well adaptation for reduce, reuse, recycle and recovery (4R concept) and minimize the waste.

iv. Suggest most appropriate pollution prevention methods with respect to each pollutant.

v. Minimize the impacts of pollutants on the ecosystems

\section{Importance of life cycle assessment}

a) Assessment of the risky activities of relevant product or project.

b) Important in the product development and improvement.

c) Environmental protection

\section{Conclusion}

As the major outcomes of the product life cycle assessment are the impact assessments regarding some process of manufacturing and product development. It is suitable for future plans and through that it will be analyzed the environmental impact of entire process or product development. The analysis is much important in the making of decisions to choose some eco friendly product or project while identifying some important phases of some products to be improved to mitigate the relent environmental impact from that phase. In the analysis of the environmental impact that related with some activity it is an essential step to consider about the impact factor for each harmful or adversely considered component.

\section{Acknowledgments}

None.

\section{Funding \\ None.}

\section{Conflicts of interest}

The authors declared that there no conflicts of interest.

\section{References}

1. Curran MA. Co-product and input allocation approaches for creating life cycle inventory data, a literature review. International Journal of Life Cycle Assessment. 2007;12:65-78.

2. Sanden BA, Karlström M. Positive and negative feedback in consequential life-cycle assessment. Journal of Cleaner Production. 2007; 15:1469-1481.

3. Finnveden G. A world with $\mathrm{CO}_{2}$ caps, Electricity production in consequential assessments. International Journal of Life Cycle Assessment. 2008;13(5):365-367.

4. Ekvall T, Tillman AM, Molander S. Normative ethics and methodology for life cycle assessment. Journal of Cleaner Production. 2005;13(1314):1225-1234.

5. Pehnt M. Dynamic life cycle assessment (LCA) of renewable energy technologies. Renewable Energy. 2006;31(1):55-57.

6. Wenzel H. Application dependency of LCA methodology: key variables and their mode of influencing the method. International Journal of LCA. 1998;3(5):281-288.

7. Reap J, Roman F, Duncan S, et al. A survey of unresolved problems in life cycle assessment. Part 1: goal and scope and inventory analysis. Int J LCA. 2008;13(4).

8. Frank C. Guidelines for life cycle assessment: a 'code of practice' from the workshop held at Sesimbra, Portugal, 31 March - 3 April 1993 Society of Environmental Toxicology and Chemistry (SETAC). 1993.

9. Heijungs R, Guinee JB. Allocation and what-if scenarios in life cycle assessment of waste management systems. Waste Management. 2007;27(8):997-1005. 